\title{
PENGARUH CURRENT RATIO, TOTAL ASSETS TURN OVER, DAN DEBT TO ASSETS RATIO TERHADAP RETURN ON ASSETS PADA PERUSAHAAN MAKANAN DAN MINUMAN YANG TERDAFTAR DI BURSA EFEK INDONESIA
}

\author{
JOANA L. SARAGIH \\ Fakultas Ekonomi Program Studi Akuntansi Universitas Katolik Santo Thomas \\ saragihjoana@gmail.com
}

\begin{abstract}
ABSTRAK
Penelitian ini bertujuan untuk mengetahui sejauh mana pengaruh current ratio, total asset turn over dan debt to asset ratio terhadapr return on asset pada perusahaan makanan dan minuman yang terdaftar di Bursa Efek Indonesia (BEI). Untuk mencapai tujuan tersebut dirumuskan masalah " apakah current ratio, total asset turn over dan debt to asset ratio berpengaruh terhadap return on asset pada perusahaan makanan dan minuman yang terdaftar di Bursa Efek Indonesia (BEI) periode 2014-2016. Teknik pengambilan sampel yang digunakan adalah purposive sampling dengan jumlah sampel 10 perusahaan. Data diperoleh dari www.idx.co.id dari tahun 2014-2016. Teknik analisis data yang digunakan dalam penelitian ini adalah analisis regresi linier berganda dan pengujian hipotesis menggunakan uji t dan uji f dengan tigkat signifikansi sebesar $5 \%$. Hasil uji parsial (uji t) menunjukkan bahwa current ratio berpengaruh negatif dan tidak signifikan terhadap return on asset, total asset turn over berpengaruh positif dan signifikan terhadap retun on asset, dan debt to asset ratio berpengaruh positif dan tidak signifikan terhadap retun on asset. Hasil Uji secara simultan (uji f) menunjukkan bahwa current ratio, total asset turn over dan debt to asset ratio berpengaruh positip dan signifikan terhadap return on asset.
\end{abstract}

Kata Kunci : current ratio, total asset turn over, debt to asset ratio, dan return on asset.

\section{PENDAHULUAN}

Analisis laporan keuangan bertujuan untuk mengetahui kondisi keuangan dan dapat membantu pihak yang berkepentingan terhadap perusahaan dalam mengambil keputusan. Analisis rasio merupakan salah satu alat analisis laporan keuangan. Rasio keuangan yang dibahas dalam penelitian ini adalah current ratio, total to asset ratio, debt to asset ratio, dan return on asset.

Current ratio merupakan ratio untuk kemampuan perusahaan dalam membayar kewajiban jangka pendek atau utang yang segera jatuh tempo pada saat di tagih secara keseluruhan. Apabila tingkat current ratio baik, maka perusahaan akan efektif dalam menghasilkan laba dan hal ini mengakibatkan laba yang diperoleh meningkat sehingga profitabilitas meningkat, dan terdapat pengaruh Current ratio terhadap profitabilitas.

Rasio Aktivitas merupakan rasio yang digunakan untuk mengukur efektifitas perusahaan dalam menggunakan asset yang dimilikinya. Semakin besar aktivitas yang berarti kemampuan perusahaan dalam menghasilkan laba semakin meningkat, sehingga manejemen menberikan informasi laporan keuangan yang terinci, karena ingin menyakinkan investor akan kinerja perusahaan.

Total Asset Turn Over Ratio (TATO) berfungsi untuk mengukur aktivitas dan kemampuan perusahaaan dalam menghasilkan penjualan melalui penggunaan aktiva perusahaan. Semakin besar TATO menunjukkan semakin efisien penggunaan seluruh aktiva perusahaan untuk menunjang kegiatan penjualan.

Rasio solvabilitas merupakan ratio yang menggambarkan hubungan antara hutang perusahaan terhadap modal maupun asset. Semakin besar solvabilitas menunjukkan besarnya resiko dalam pembayaran hutang perusahaan.

Debt to Asset Ratio (DAR) menunjukkan perbandingan antara total hutang dengan total asset. Semakin tinggi DAR menunjukkan semakin tinggi penggunaan hutang sebagai sumber pendanaan perusahaaan..

Return on Asset (ROA) adalah suatu bentuk dari rasio profitabilitas yang sering digunakan untuk mengukur kemampuan suatu perusahaan dalam menghasilkan keuntungan dari setiap rupiah 
modal sendiri yang digunakan untuk operasi oleh suatu perusahaan selama periode tertentu. Semakin tinggi ROA menunjukkan semakin efisien penggunaan asset yang dimiliki perusahaan.

Tujuan dari penelitian ini adalah untuk mengetahui pengaruh current ratio, total to asset ratio, debt to asset ratio, terhadap return on asset pada perusahaan makanan dan minuman yang terdaftar di Bursa Efek Indonesia tahun 2014-2016. Berdasarkan latar belakang masalah yang telah diuraikan diatas, maka penulis merumuskan masalah penelitian sebagai berikut : apakah current ratio, total asset turn over, dan debt to asset ratio berpengaruh terhadap return on asset pada perusahaan makanan dan minuman yang terdaftar di Bursa Efek Indonesia pada tahun 2014-2016.

\section{TINJAUAN PUSTAKA DAN HIPOTESIS}

a. Current Ratio

Menurut Brigham Housten (2010:134) Current ratio menunjukkan sampai sejauh apa kewajiban lancar ditutupi oleh asset yang diharapkan akan di konversi menjadi kas dalam waktu dekat pada saat di tagih secara keseluruhan.

b. Total Asset Turnover

Total Asset Turnover adalah rasio yang digunakan untuk mengukur perputaran seluruh asset yang dimiliki perusahaan dan mengukur berapa jumlah penjualan yang diperoleh dari tiap rupiah aktiva, Brigham Housten (2010:139).

c. Total Debt to Asset Ratio

Debt to Equity Ratio merupakan rasio utang yang digunakan untuk mengukur perbandingan antara total utang dengan total aktiva. Dengan kata lain, seberapa besar aktiva perusahaan dibiayai oleh utang atau seberapa besar utang perusahaan berpengaruh terhadap pengelolaan aktiva.

d. Return on Asset

Return on Asset (ROA) merupakan salah satu rasio profitabilitas yang menunjukkan kemampuan perusahaan dalam memperoleh laba dari kekayaan atau aktiva yang digunakan. ROA penting bagi manajemen untuk mengukur kinerja keuangan perusahaan dan menilai kinerja operasional dalam memanfaatkan sumber daya yang dimiliki perusahaan

Hipotesis dalam penelitian ini adalah sebagai berikut:

$\mathrm{H}_{1}$ : Current ratio berpengaruh positif dan signifikan terhadap return on assets pada perusahaan makanan dan minuman yang terdaftar di Bursa Efek Indonesia Tahun 2014-2016.

$\mathrm{H}_{2}$ : Total asset turn over berpengaruh positif dan signifikan terhadap return on assets pada perusahaan makanan dan minuman yang terdaftar di Bursa Efek Indonesia Tahun 20142016.

$\mathrm{H}_{3}$ : Debt to asset ratio berpengaruh positif dan signifikan terhadap return on assets pada perusahaan makana dan minuman yang terdaftar di Bursa Efek Indonesia Tahun 20142016.

\section{METODE PENELITIAN}

\section{Populasi danSampel}

Populasi dalam penelitian ini adalah seluruh perusahaan manufaktur yang terdaftar di Bursa Efek Indonesia tahun 2014- 2016. Sampel dalam penelitian ini yaitu seluruh perusahaan makanan dan minuman yang terdaftar di Bursa Efek Indonesia tahun 2014-2016. Teknik pengambilan sampel dengan Purposive Sampling, sehingga di peroleh sampel sebanyak 10 perusahaan.

\section{Operasionalisasi Variabel}

a. Current Ratio

Current Ratio yaitu mengukur kemampuan perusahaan untuk membayar hutang jangka pendeknya, untuk mengukur tingkat keamanan suatu perusahaan yang dapat dilakukan dengan membandingkan antara total aktiva lancar dengan utang lancar. Skala pengukurannya adalah skala rasio yang diukur dengan rumus :

$$
\text { Current Ratio }=\frac{\text { Current Asset }}{\text { Current Liabilities }} \times 100 \%
$$


Dipilihnya Current Ratio dalam penelitian ini karena Current Ratio merupakan ukuran yang paling umum digunakan untuk mengetahui kesanggupan suatu perusahaan dalam memenuhi kewajiban jangka pendeknya dan untuk mengetahui seberapa besar modal kerja yang dialokasikan untuk operasi perusahaan.

\section{b. Total Asset Turn Over}

Total Asset Turn over yaitu rasio yang digunakan untuk mengukur perputaran semua aktiva yang dimiliki perusahaan, dan mengukur berapa jumlah penjualan yang diperoleh dari setiap rupiah aktiva. Skala pengukurannya adalah skala rasio dengan rumus :

Total Asset Turnover $=\frac{\text { Penjualan }}{\text { Total Aktiva }} \times 100 \%$

Dipilihnya Total Asset Turn Over dalam penelitian ini karena Total Asset Turn Over merupakan ukuran untuk mengetahui besarnya penjualan yang dihasilkan oleh setiap rupiah aktiva.

\section{c. Debt to Asset Ratio}

Debt to Asset Ratio yaitu komposisi pendanaan yang akan diukur dari rasio utang terhadap ekuitas. Skala pengukurannya adalah skala rasio dengan rumus :

$$
\text { Debt to Asset Ratio }=\frac{\text { Total } \mathrm{Hutang}}{\text { Total } \text { Asset }} \times 100 \%
$$

Dipilihnya Debt to Asset Ratio dalam penelitian ini karena Debt to Asset Ratio merupakan rasio yang memperlihatkan proporsi antara kewajiban yang dimiliki perusahaan, sehingga rasio ini menunjukkan sejauh mana hutang dapat ditutupi oleh asset dalam perusahaan.

d. Return on Asset merupakan kemampuan perusahaan dalam menghasilkan laba melalui keseluruhan assets nya. Skala pengukurannya adalah skala rasio dengan rumus :

$$
\text { Return on Asset }=\frac{\text { Laba Bersih }}{\text { Total } \text { Asset }} \times 100 \%
$$

Dipilihnya Return on Asset dalam penelitian ini karena Retun on Asset merupakan rasio yang digunakan untuk mengukur kinerja keuangan perusahaan dan menilai kinerja operasional dalam memanfaatkan sumber daya yang dimiliki perusahaan.

\section{Teknik Analisis Data}

Teknik analisis data dalam penelitian ini adalah analisis regresi linier berganda. Persamaan regresi sebagai berikut.

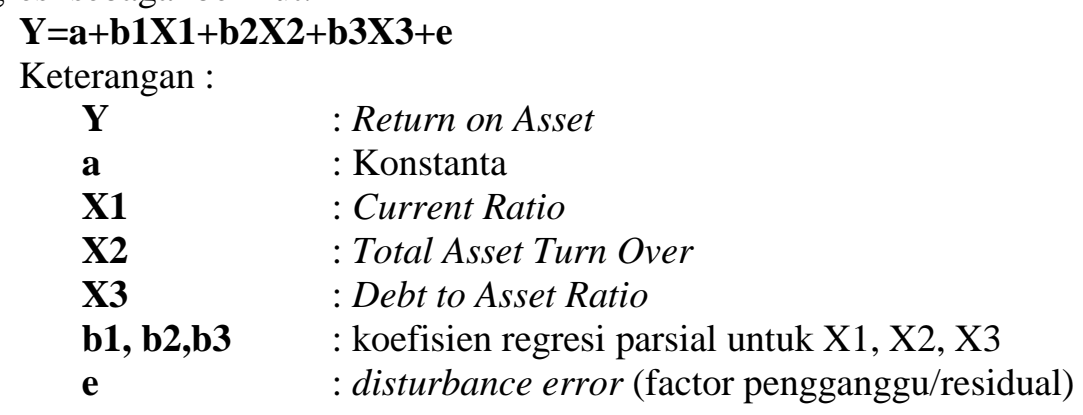

\section{HASIL PENELITIAN DAN PEMBAHASAN \\ 1. Pengujian Asumsi Klasik \\ a. Uji Normalitas}

Analisis grafik dapat digunakan dengan dua alat, yaitu grafik histogram, data yang mengikuti atau mendekati distribusi normal adalah distribusi data dengan bentuk lonceng. Adapun grafik histogram penelitian ini terlihat pada gambar berikut ini: 


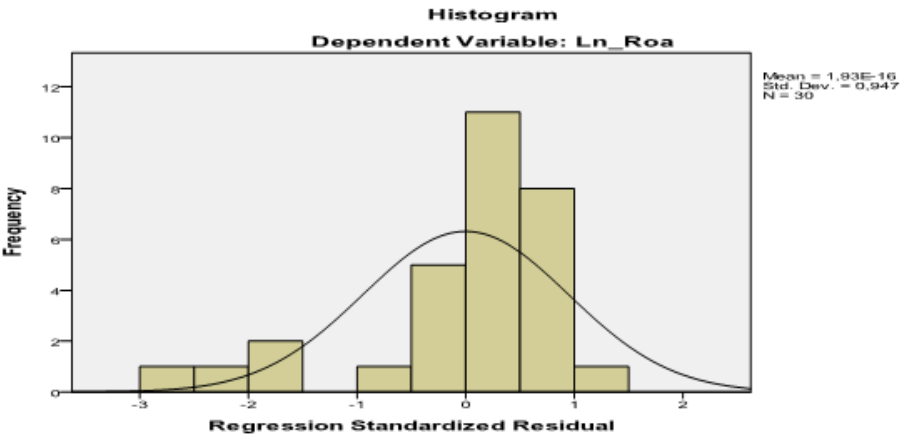

Gambar 1. Grafik Histogram

Sumber: Hasil Output SPSS 19s (Data diolah)

Dari gambar di atas kita dapat melihat bahwa gambarnya berbentuk lonceng dan tidak menceng, kekanan atau kekiri yang menunjukkan bahwa data telah terdostribusi secara normal.

\section{b. Uji Mulitikolonearitas}

Pengujian ini dilakukan dengan toleransi value dan variance factor (VIF) Tolerance mengukur variabilitas variabel independen yang terpilih yang tidak dijelaskan oleh variabel independen lainnya. Jadi, nilai tolerance yang rendah sama dengan nilai VIF yang tinggi (karena $\mathrm{VIF}=1 /$ tolerance). Nilai cutof yang umum dipakai untuk menunjukkan adanya multikolinearitas adalah nilai tolerance $<0,10$ atau sama dengan $\mathrm{VIF}>10$.

Adapun hasil uji multikolonearitas pada penelitian ini dapat dilihat pada tabel berikut ini:

Tabel 1. Hasil Uji Multikolinearitas Coefficients ${ }^{\mathrm{a}}$

\begin{tabular}{|c|c|c|c|c|c|c|c|c|}
\hline \multirow{2}{*}{\multicolumn{2}{|c|}{ Model }} & \multicolumn{2}{|c|}{$\begin{array}{l}\text { Unstandardized } \\
\text { Coefficients }\end{array}$} & \multirow{2}{*}{$\begin{array}{l}\text { Standardized } \\
\text { Coefficients } \\
\text { Beta }\end{array}$} & \multirow[b]{2}{*}{$\mathrm{t}$} & \multirow[b]{2}{*}{ Sig. } & \multicolumn{2}{|c|}{$\begin{array}{l}\text { Collinearity } \\
\text { Statistics }\end{array}$} \\
\hline & & B & Std. Error & & & & $\begin{array}{l}\text { Toleranc } \\
\mathrm{e}\end{array}$ & VIF \\
\hline \multirow[t]{4}{*}{1} & (Constant & 1,181 & 1,712 & & 689 & ,497 & & \\
\hline & $\mathrm{Cr}$ &,- 338 & ,283 &,- 297 & $-1,195$ & 243 & ,587 & 1,703 \\
\hline & Tato & ,379 & ,358 & ,260 & 2,557 & 035 & ,599 & 1,670 \\
\hline & Dar & ,138 & ,257 &, 122 &, 538 & ,595 & 699 & 1,430 \\
\hline
\end{tabular}

a. Dependent Variable: Ln_Roa

Sumber :Hasil Output SPSS 19 (data diolah)

Berdasarkan tabel diatas dapat dilihat bahwa Tolerance Value $>0,10$ dan VIF $<10$, sehingga dapat disimpulkan bahwa diantara variabel bebas tersebut tidak terdapat hubungan multikolonieritas. Dari hasil uji ini maka dapat disimpulkan bahwa semua variable bebas yang digunakan dalam penelitian ini lolos uji gejala multikolonieritas.

\section{Uji Autokolerasi}

Uji autokolerasi bertujuan untuk menguji apakah dalam model regresi linear ada kolerasi antara kesalahan antara kesalahan pengganggu pada periode $t$ dengan kesalahan pengganggu pada periode - $\mathrm{t}$ (sebelumnya). Jika terjadi kolerasi maka ada masalah autokolerasi. Model regresi yang baik adalah model regresi yang bebas dari autokolerasi. Untuk menentukan ada atau tidaknya autokolerasi dalam penelitian ini dengan menggunakan Durbin-Watson.

Tabel 2. Hasil Uji Autokorelasi Model Summary ${ }^{b}$

\begin{tabular}{|l|l|l|l|l|l|}
\hline Model & $\mathrm{R}$ & $\mathrm{R}$ Square & $\begin{array}{l}\text { Adjusted R R } \\
\text { Square }\end{array}$ & $\begin{array}{l}\text { Std. Error of } \\
\text { the Estimate }\end{array}$ & $\begin{array}{l}\text { Durbin- } \\
\text { Watson }\end{array}$ \\
\hline 1 &, $244^{\mathrm{a}}$ &, 060 &,- 049 & 1,85127 & 2,242 \\
\hline
\end{tabular}


Tabel 2. Hasil Uji Autokorelasi Model Summary ${ }^{b}$

\begin{tabular}{|l|l|l|l|l|l|}
\hline Model & $\mathrm{R}$ & $\mathrm{R}$ Square & $\begin{array}{l}\text { Adjusted } \\
\text { Square }\end{array}$ & $\begin{array}{l}\text { Std. Error of } \\
\text { the Estimate }\end{array}$ & $\begin{array}{l}\text { Durbin- } \\
\text { Watson }\end{array}$ \\
\hline 1 &, $244^{\mathrm{a}}$ &, 060 &,- 049 & 1,85127 & 2,242 \\
\hline
\end{tabular}

a. Predictors: (Constant), Ln_Dar, Ln_Tato, Ln_Cr

b. Dependent Variable: Ln_Roa

Sumber :Hasil Output SPSS 19 (data diolah)

Berdasarkan tabel diatas, dapat dilihat bahwa nilai Durbin-Watson (DW) sebesar 2,242. Nilai ini akan dibandingkan dengan nilai table dengan menggunakan $\alpha=5 \%, \mathrm{n}=30, \mathrm{k}=3$. Berdasarkan tabel DW didapatkan nilai batas bawah $(\mathrm{dL})=1,2138$ dan nilai batas atas $(\mathrm{dU})=$ 1,6498. Dengan demikian nilai $\mathrm{dU}<\mathrm{d}<4$-dU $(1,6498<2,199<1,6498)$. Hasil tersebut menunjukkan bahwa model yang digunakan tidak ada autokorelasi positif maupun negatif (bebas uji autokorelasi)

\section{Uji Heteroskedastisitas}

Pengujian ini bertujuan untuk menguji apakah terjadi ketidaksamaan variandan residual satu pengamatan kepengamatan lain dalam model regresi. Model penelitian yang baik adalah homoskedastisitas, yaitu varian dan residual satu pengamatan kepengamatan yang lain hasilnya tetap. Dalam penelitian ini digunakan diagram titik (scatter plot) yang seharusnya titik-titik tersebut tersebar acak agar tidak terdapat heteroskedastisitas. Adapun hasil uji heteroskedastisitas dalam penelitian ini disajikan berikut ini.

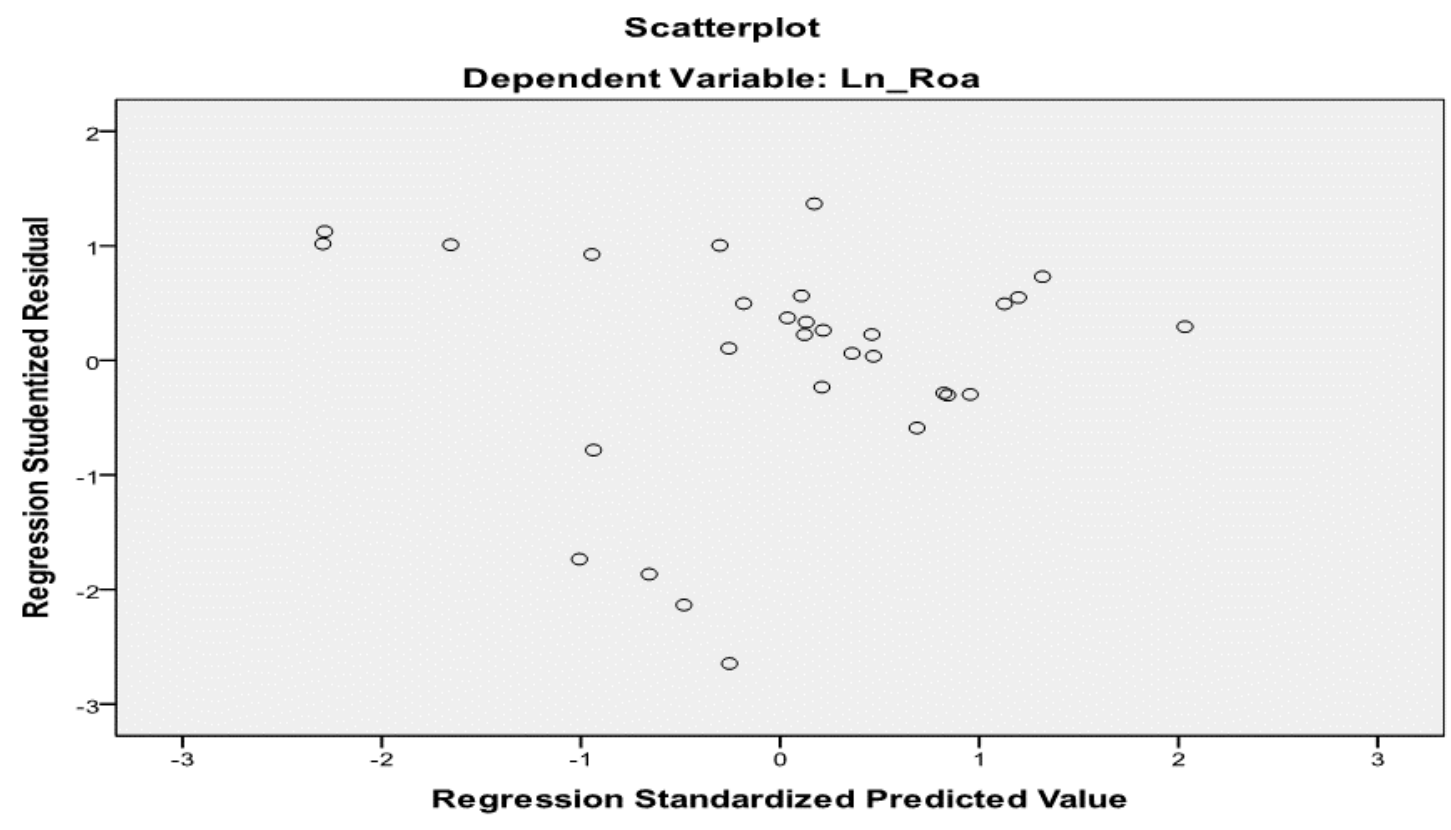

Gambar 2. Hasil Uji Heteroskedastisitas

Sumber :Hasil Output SPSS 19 (data diolah)

Dari grafik scatterplot diatas dapat dilihat bahwa titik-titik menyebar secara acak, serta tersebar baik diatas maupun dibawah angka 0 pada sumbu Y. Hal ini dapat disimpulkan bahwa tidak terjadi heteroskedastisitas pada model regresi yang digunakan

\section{Regresi Linier Berganda}

Tabel 3. Regresi Linier Berganda Coefficients ${ }^{\mathrm{a}}$ 


\begin{tabular}{|c|c|c|c|c|c|c|}
\hline \multirow{2}{*}{\multicolumn{2}{|c|}{ Model }} & \multicolumn{2}{|c|}{$\begin{array}{l}\text { Unstandardized } \\
\text { Coefficients }\end{array}$} & \multirow{2}{*}{$\begin{array}{l}\text { Standardize } \\
\mathrm{d} \\
\text { Coefficients } \\
\text { Beta }\end{array}$} & \multirow[b]{2}{*}{$\mathrm{T}$} & \multirow[b]{2}{*}{ Sig. } \\
\hline & & $\mathrm{B}$ & Std. Error & & & \\
\hline 1 & (Constant & 1,181 & 1,712 & &, 689 &, 497 \\
\hline & $\mathrm{Cr}$ &,- 338 & ,283 &,- 297 & $-1,195$ &, 243 \\
\hline & Tato & ,379 & ,358 & ,260 & 2,557 &, 035 \\
\hline & Dar & ,138 & ,257 &, 122 & ,538 &, 595 \\
\hline
\end{tabular}

a. Dependent Variable: ROA

Sumber: Hasil Output SPSS 19 (Data Diolah)

Berdasarkan tabel tersebut maka persamaan regresi linear berganda adalah :

Return On Asset $=1,181-0,338$ Current Ratio $+0,379$ Total Asset Turn Over + 0,138 Debt To Asset Ratio

Dimana:

$$
\begin{aligned}
& \mathrm{Y}=\text { Retun On Asset } \\
& \mathrm{X} 1=\text { Current Ratio } \\
& \mathrm{X} 2=\text { Total Asset Turn Over } \\
& \mathrm{X} 3=\text { Debt To Asset Ratio }
\end{aligned}
$$

\section{Uji Statiktik Deskriptif}

Tabel 4. Statistik Deskriptif Descriptive Statistics

\begin{tabular}{|l|l|l|l|}
\hline & Mean & Std. Deviation & $\mathrm{N}$ \\
\hline Roa & 1,7104 & 1,80753 & 30 \\
Cr & 4,8280 & 1,58356 & 30 \\
Tato & 4,3487 & 1,24030 & 30 \\
Dar & 3,7467 & 1,60150 & 30 \\
\hline
\end{tabular}

Sumber: Hasil Output SPSS 19 (Data Diolah)

\begin{tabular}{|c|c|c|c|c|c|c|}
\hline \multirow{2}{*}{\multicolumn{2}{|c|}{ Model }} & \multicolumn{2}{|c|}{$\begin{array}{l}\text { Unstandardized } \\
\text { Coefficients }\end{array}$} & \multirow{2}{*}{ 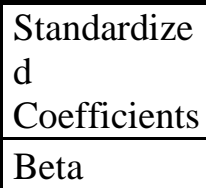 } & \multirow[b]{2}{*}{$\mathrm{t}$} & \multirow[b]{2}{*}{ Sig. } \\
\hline & & B & Std. Error & & & \\
\hline \multirow[t]{4}{*}{1} & (Constant & 1,181 & 1,712 & & ,689 & ,497 \\
\hline & $\mathrm{Cr}$ &,- 338 &, 283 &,- 297 & $-1,195$ & ,243 \\
\hline & Tato & ,379 &, 358 & ,260 & 2,557 & 035 \\
\hline & Dar &, 138 & ,257 &, 122 &, 538 & ,595 \\
\hline
\end{tabular}

\section{Pengujian Hipotesis}

a. Hasil Uji Parsial (uji t)

Tabel 5. Hasil Uji secara Parsial (Uji t ) Coefficients ${ }^{\mathrm{a}}$

b. Dependent Variable: ROA

Sumber: Hasil Output SPSS 19 (Data Diolah)

Berdasarkan hasil uji statistik pada tabel diatas menunjukkan bahwa thitung current ratio (CR) sebesar $-1,195<$ dari table yaitu 2,447, dengan tingkat signifikan sisebesar 0,243>0,05 maka Ho diterima, yang berarti bahwa current ratio berpengaruh negatif dan tidak signifikan terhadap return on asset. 
TATO memiliki $\mathrm{t}_{\text {hitung }}$ sebesar 2,557 $>$ dari $\mathrm{t}_{\text {tabel }}$ yaitu 2,447 dengan tingkat signifikansi sebesar $0,035<0,05$ maka $\mathrm{H}_{0}$ ditolak, yang berarti bahwa total asset turn over berpengaruh positif dan signifikan terhadap Return On Asset.

DAR memiliki $t_{\text {hitung }}$ sebesar $0,538<$ dari table yaitu 2,447 dengan tingkat signifikansi sebesar 0,595 > 0,05 maka $\mathrm{H}_{0}$ diterima, yang berarti bahwa debt to asset ratio berpengaruh positif dan tidak signifikan terhadap return on asset.

\section{b.Hasil Uji Simultan (Uji F)}

Tabel 6. Hasil Uji secara simultan (Uji F) ANOVA ${ }^{\text {b }}$

\begin{tabular}{|ll|l|l|l|l|l|}
\hline \multicolumn{2}{|l|}{ Model } & $\begin{array}{l}\text { Sum } \\
\text { Squares }\end{array}$ & Df & Mean Square & F & Sig. \\
\hline 1 & Regression & 5,641 & 3 & 1,880 &, 549 &, $045^{\mathrm{a}}$ \\
& Residual & 89,107 & 26 & 3,427 & & \\
& Total & 94,748 & 29 & & & \\
\hline
\end{tabular}

a. Predictors: (Constant), Ln_Dar, Ln_Tato, Ln_Cr

b. Dependent Variable: Ln_Roa

Sumber: Hasil Olah SPSS 19 (Hasil Diolah)

Berdasarkan tabel di atas menunjukkan bahwa nilai signifikan dari model penelitian ini adalah sebesar 0,045 dimana 0,045 $<0,05$ dan nilai $F_{\text {hitung }} 0,549>4,35$ sehingga Ho diterima. Dengan demikian variabel-variabel current ratio, total asset turn over, debt to asset ratio tidak mempunyai pengaruh signifikan terhadap return on .asset.

\section{PEMBAHASAN}

1. Pengaruh current ratio terhadap return on asset pada perusahaan makanan dan minuman yang terdafar di Bursa Efek Indonesia.

Berdasarkan hasil analisis uji t untuk Current ratio memiliki nilai sig. sebesar 0,243 dimana $0,243>0,05$ dan nilai $\mathrm{t}_{\text {hitung }}-1,195<$ dari $\mathrm{t}_{\text {table }}$ yaitu 2,447 , dengan tingkat signifikansi sebesar 0,243 > 0,05 maka Ho diterima, yang berarti bahwa current ratio secara parsial berpengaruh negatif dan tidak signifikan terhadap return on asset sehingga hipotesis current ratio berpengaruh positip positip dan signifikan terhadap return on asset ditolak.

Semakin tinggi rasio Current ratio maka semakin likuid perusahaan dalam meningkatkan laba perusahaan, dan setiap perusahaan harus mampu memenuhi likuiditasnya sehingga akan meningkatkan tingkat kepercayaan pihak luar terhadap kelancaran usahanya. Apabila current ratio tinggi menunjukkan jaminan lebih baik atas hutang jangka pendeknya, tetapi apabila terlalu tinggi dapat berakibat pada modal kerja yang tidak efisien. Current ratio yang rendah akan memberikan image yang kurang baik. Rendahnya current ratio yang dimiliki perusahaan mencerminkan adanya masalah dalam likuiditas, Kasmir (2012:185). Akan tetapi current ratio yang terlalu tinggi juga kurang baik karena menunjukkan banyaknya dana menganggur yang pada akhirnya dapat mempengaruhi kemampuan perusahaan dalam memperoleh laba. Tingkat current ratio perusahaan yang baik berarti bahwa penurunan laba, karena laba operasi banyak dipergunakan untuk melakukan pembayaran utang jangka pendeknya, hal ini berakibat pada adanya penurunan laba dan penurunan dari utang jangka pendeknya sehingga mengakibatkan current ratio meningkat dan retun on asset menjadi menurun.

\section{Pengaruh total asset turn over terhadap return on asset pada perusahaan makanan dan minuman yang terdaftar di Bursa Efek Indonesia}

Berdasarkan uji analisis t untuk variabel aktivitas (TATO) menunjukkan nilai Sig sebesar 0,035 dimana $0,035<0,05$ memiliki nilai $t_{\text {hitung }}$ sebesar 2,557 dan nilait tabel yaitu 2,447 sehingga, Ha diterima yang berarti bahwa total asset turn over berpengaruh positif dan signifikan terhadap return on asset sehingga hipotesis yang menyatakan total asset turn over berpengaruh positif dan signifikan terhadap return on asset diterima.

Semakin tinggi total asset turn over berarti kemampuan perusahaan dalam menghasilkan laba semakin meningkat, sehingga manajemen perusahaan dalam menghasilkan laba semakin 
meningkat, sehingga manajemen memberikan informasi laporan keuangan yang terinci karena ingin menyakinkan invertor supaya operasional dalam perusahaan berjalan dan menghasilkan laba yang maksimal, Semakin menurun total asset turn over berrarti tingkat penjualan dalam perusahaan menurun dan berpengaruh buruk terhadap perusahaan dalam memperoleh laba karena semakin menurun tingkat penjualan dalam perusahaan maka laba yang akan diperoleh juga akan menurun sehingga tidak efisen dalam memperoleh laba. Dalam penelitian ini Total Asset Turn Over berpengaruh positif dan signifikan terhadap Return on Asset.

\section{Pengaruh debt to asset ratio terhadap return on asset pada perusahaan makanan dan minuman yang terdaftar di Bursa Efek Indonesia.}

Berdasarkan hasil analisis, Debt to Asset Ratio menunjukkan nilai thitung 0,538 lebih kecil dari $t_{\text {tabel }} 2,447(0,538<2,447)$ dengan tingkat signifikansi 0,595 artinya Ho di terima maka Debt to Asset Ratio berpengaruh positif dan tidak signifikan sehingga hipotesis yang menyatakan bahwa Debt to Asset Ratio berpengaruh positip terhadap Return On Asset ditolak.

Semakin tinggi debt to asset ratio semakin tinggi pula penggunaan hutang oleh perusahaan yang dibandingkan dengan total aktiva ataupun dengan modal sendiri, Kasmir (2012:159). Debt to Asset ratio yang tinggi menunjukkan penggunaan hutang sebagai sumber pendanaan perusahaan juga meningkat. Hal ini dapat menimbulkan resiko yang cukup besar bagi perusahaan ketika perusahaan tidak mampu membayar kewajiban tersebut pada saat jatuh tempo, sehingga akan mengganggu kontinuitas operasi perusahaan, Selain itu perusahaan akan dihadapkan pada biaya bunga yang tinggi sehingga dapat menurunkan laba. Jika Debt to Asset Ratio yang rendah maka penggunaan hutang dalam perusahaan juga menurun yang mengakibatkan jiak hutang dalam perusahaan menurun maka sangat berpengaruh baik terhadap laba karena laba perusahaan akan semakin meningkat.

4. Pengaruh current ratio, total asset turn over dan debt to asset ratio terhadap return on assets perusahaan makanan dan minuman yang terdaftar di Bursa Efek Indonesia.

Berdasarkan hasil uji statistik $\mathrm{F}$ diatas, terlihat bahwa nilai signifikansi sebesar 0,045 dimana nilai tersebut tidak signifikansi 0,05 karena 0,45 lebih kecil dari 0,05 . Dalam penelitian ini juga diperoleh nilai $F$ hitung 0,549 dan Ftabel sebesar 4,35 yang artinya nilai Fhitung 0,549< Ftabel 4,35 dengan tingkat signifikansi 0,045 $<0,05$ artinya Current Ratio, Total Asset Turn Over dan Debt to Asset Ratio berpengaruh positip dan signiikan terhadap Return On Assets.

\section{KESIMPULAN}

1. Current ratio dengan nilai $t_{\text {hitung }}$ sebesar $-1,195$ < dari $t_{\text {tabel }}$ sebesar 2,447 dengan tingkat signifikansi sebesar 0,243>0,05 yang berarti Current Ratio berpengaruh negatif dan tidak signifikan terhadap Return on Asset pada perusahaan makanan dan minuman yang terdaftar Bursa Efek Indonesia tahun 2014-2016.

2. Total Asset Turn Over dengan nilai $t_{\text {hitung }}$ sebesar 2,557 < dari $t_{\text {tabel }}$ sebesar 2,447 dengan tingkat signifikansi sebesar 0,035 $<0,05$ yang berarti Total Asset Turn Over berpengaruh positif dan signifikan terhadap Return on asset pada perusahaan makanan dan minuman yang terdaftar di Bursa efek Indonesia tahun 2014-2016.

3. Debt To Asset Ratio dengan nilai $t_{\text {hitung }}$ sebesar $0,538<$ dari $t_{\text {tabel }}$ sebesar 2,447 dengan tingkat signifikansi 0,595>0,05 yang berarti Debt to asset ratio berpengaruh positif dan tidak signifikan terhadap Return on asset pada perusahaan makanan dan minuman yang terdaftar di Bursa Efek Indonesia tahun 2014-2016.

4. Current ratio, Total asset turn over dan Debt to asset ratio secara bersama-sama berpengaruh positip dan signifikan terhadap Return On assets asset pada perusahaan makanan dan minuman yang terdaftar di Bursa Efek Indonesia tahun2014-2016 sebesar 0,045 dimana 0,045 < 0,05 dan $F_{\text {hitung }}$ sebesar $0,549<F_{\text {tabel }}$ sebesar. $045^{\mathrm{a}}$

\section{DAFTAR PUSTAKA}

Amin, Widjaja Tunggal. (2000). Dasar-Dasar Analisis Laporan Keuangan. Jakarta: Rineka Cipta. 
Bursa Efek Indonesia. Laporam keuangan Tahunan Bursa Efek Indonesia www.idx.co.id dan fact Book www.idx.co.id.

Bambang, Riyanto. (2001).“Dasar-Dasar Pembelanjaan Perusahaan”. Yogyakarta: BPFE Yogyakarta.

Brigham, Eugene F., dan Houston, Joel. F. 2001. Manajemen Keuangan. Edisi Kedelapan. Jakarta: Erlangga.

Djarwanto, 2001.Analisis Laporan Keuangan, BPFE, Yogyakarta.

Elyas setiawan. 2015. "Pengaruh Current ratio,Inventory Turn Over,Debt to equity Ratio,Total Asset Turn Over, Sales dan Firm Size terhadap Return On Asset pada perusahaan food and beverange yang terdaftar di Bursa efek Indonesia.

Ghozali, Imam. 2006. Aplikasi Analisis Multivarisate dengan Program SPSS. Semarang: Badan Penerbit Universitas Diponegoro.

Harahap, Sofian Syafri. 2008. Analisis Kritis atas Laporan Keuangan. Jakarta: Rajawali Press.

Kasmir. 2012.Analisis Laporan Keuangan. Jakarta: PT. Raja Grafindo Persada.

Munawir, S. 2002. Analisis Laporan Keuangan. Edisi keempat. Yogyakarta: Liberty.

Marbun, Mahardika. 2010. "Pengaruh Current ratio, Debt to equity ratio terhadap Return on Asset pada kelompok industri alas kaki yang terdaftar di Bursa Efek Indonesia.

Ni Putu Juni, Candrawita (2016). “Analisis Pengaruh Likuiditas, Dan Aktivitas Terhadap Profitabilitas Pada Perusahaan Makanan Dan Minuman Yang Terdaftar Di Bursa Efek Indonesia Periode 2010-2014”. Skripsi. Universitas Lampung.

Putri, 2010. "Pengaruh rasio likuiditas, rasio solvabilitas dan rasio aktivitas terhadap profitabilitas pada perusahaan logam yang terdaftar di Bursa Efek Indonesia.

Sundjaja, Ingeberlian. 2002. Manajemen Keuangan. Edisi kelima. Jakarta: Literata Lintas Media. 